\title{
RESPIRATION AND FERMENTATION DURING GROWTH AND STARVATION IN THE FISSION YEAST, SCHIZOSACCHAROMYCES POMBE
}

\author{
by
}

\author{
KIRSTEN HAMBURGER ${ }^{1}$ and BIRTE KRAMHØFT ${ }^{2}$
}

\author{
Biological Institute of the Carlsberg Foundation \\ Tagensvej 16, DK-2200 Copenhagen N \\ Present address: ' Freshwater Biological Laboratory, \\ Helsingørsgade 51, DK-3400 Hillerød \\ 2 Institute of Biological Chemistry A, \\ Universitetsparken 13, DK-2100 Copenhagen Ø
}

Keywords: Schizosaccharomyces, respiration, fermentation, growth cycle, nitrogen-depletion

\begin{abstract}
Respiration and fermentation in cultures of Schizosaccharomyces pombe were studied under various growth conditions. It was found that during the transition from exponential growth to stationary phase, the rate of fermentation decreases whereas the rate of oxygen uptake remains unchanged. Thus, no activation of respiration in stationary phase was found. When exponentially multiplying cells are deprived of nitrogen, the rate of oxygen uptake increases whereas the rate of fermentation is somewhat lowered. Therefore, in S. pombe, cessation of growth, whether induced by stationary phase conditions or by nitrogen starvation, results in suppression of fermentation and thus induction of a more aerobic mode of metabolism.
\end{abstract}

\section{INTRODUCTION}

The respiratory metabolism of the petite negative yeast, Schizosaccharomyces pombe has been studied by HesLot et al. (4). Under aerobic conditions Schizosaccharomyces grows fast with glucose, more slowly with glycerol and only poorly with ethanol as carbon source. Limited growth was found under anaerobic conditions and only in the presence of an oxidant. Under aerobic conditions the fermentation rate is high and the respiration rate relatively low, resulting in a high respiratory quotient. Thus, glucose re- pression of respiration is observed in Schizosaccharomyces as in many other yeasts, though this phenomenon is more pronounced in the petite positive yeasts such as Saccharomyces (2).

The present study deals with the influence of various nutritional conditions on respiration and fermentation. Our results show that cessation of growth, whether induced by stationary phase conditions or by nitrogen deprivation, results in partial suppression of fermentation and thus induction of a more aerobic mode of metabolism. 


\section{MATERIALS AND METHODS}

Stock and "starter" cultures of Schizosaccharomyces pombe strain $972 \mathrm{~h}^{-}$, were kept and handled as described earlier (6). The growth medium was "Edinburgh Minimal Medium" No. 2 (EMM 2), which contains an inorganic nitrogen source $\left(\mathrm{NH}_{4} \mathrm{Cl}\right)$, salts, vitamins, trace elements and $1 \%$ glucose (11). Cultures were grown in 250 $\mathrm{ml}$ Erlenmeyer flasks with $100 \mathrm{ml}$ growth medium at $32{ }^{\circ} \mathrm{C}$ in a shaking water bath.

Nitrogen depletion was obtained by resuspending cells from an exponentially multiplying culture, collected on a Millipore membrane filter (pore size $0.45 \mu \mathrm{m}$ ), in $\mathrm{NH}_{4} \mathrm{Cl}$-free EMM 2 . Ammonium chloride was substituted with equiosmolar concentrations of $\mathrm{KCl}$, sorbitol or choline chloride.

Gaseous exchanges $\left(\mathrm{O}_{2}\right.$ uptake or $\mathrm{CO}_{2}$ production) were measured on samples of growing or nitrogen depleted cultures using the conventional Warburg technique (13). Details of this method when applied to cultures of Schizosaccharomyces have been described elsewhere (3). Cell numbers were calculated from counts in a Bürker-Türk hemocytometer and cellular protein was determined according to LowRY et al. with bovine serum albumine as a standard (9).

Rates of gaseous exchanges were expressed as follows: $\mathrm{QO}_{2}=\mu \mathrm{IO}_{2} \cdot \mu \mathrm{g}_{\text {protein }}{ }^{-1} \cdot \mathrm{h}^{-1}$ and $\mathrm{QCO}_{2}$ $=\mu \mathrm{l} \mathrm{CO}$ (fermentation) $\cdot \mu \mathrm{g}$ protein ${ }^{-1} \cdot \mathrm{h}^{-1}$, assuming that $R Q=1$ in respiration. The respiratory quotient $(R Q)$ is the sum of $\mathrm{CO}_{2}$ produced in respiration and fermentation relative to the oxygen uptake.

\section{RESULTS}

\subsection{Growing cultures}

During cultural growth the oxygen consumption is constant whereas the $\mathrm{CO}_{2}$ released in fermentation varies with the growth stage. This is shown in Figure 1, which shows the variation in gas exchange (A), cell number and protein per $\mathrm{ml}(\mathrm{C})$, protein content per cell (B) and RQ (D)' with time during cultural growth of Schizosaccharomyces in EMM 2 with $1 \%$ or $5 \%$ glucose. Three phases of growth can be distinguished: 1) an exponential, balanced growth phase with doubling of cell number (Figure 1C, closed triangles) and protein per $\mathrm{ml}$ (Figure $1 \mathrm{C}$, open triangles) each 2.3 hours, 2 ) a transition phase (de-
Table I.

Medium glucose concentration at various stages of cultural growth of Schizosaccharomyces pombe in EMM 2.

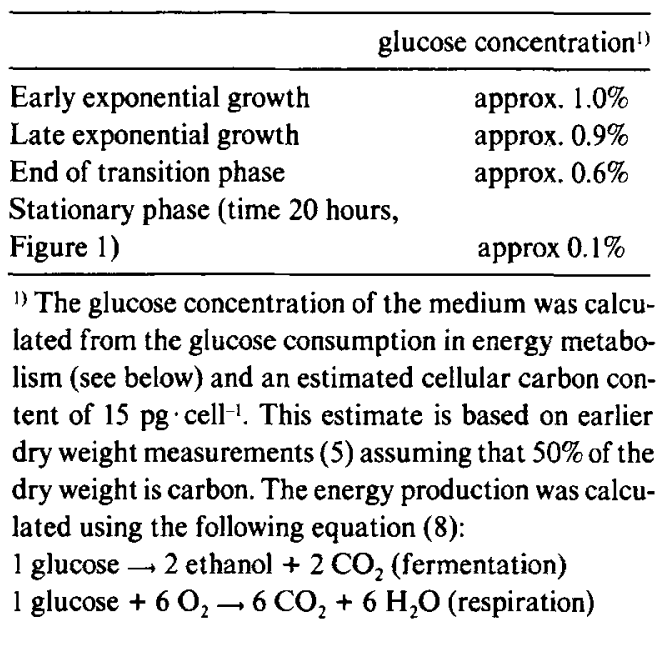

limited by vertical broken lines) of one generation time during which the rate of cell multiplication is unchanged but where the rate of protein synthesis decreases so that the protein content per cell decreases from 13 to $9 \mathrm{pg}$, and 3) a stationary phase with constant cell number and protein content.

During exponential cell multiplication $\mathrm{QCO}_{2}$ is constant 0.75-0.85 (Figure 1A, open circles), during the transition phase it decreases sharply followed by a more gradual decrease during early stationary phase. $\mathrm{QO}_{2}$ (Figure 1A, open squares) remains constant at a value of 0.11 throughout cultural growth.

The sharp decrease in $\mathrm{QCO}_{2}$ during the transition phase is parallelled by a $40 \%$ reduction in the glucose content of the medium as shown in Table

Figure 1. Gaseous exchanges and growth of Schizosaccharomyces pombe during cultural growth.

A: oxygen uptake and $\mathrm{CO}_{2}$ production. $\square: \mathrm{QO}_{2}$ in EMM 2. : $\mathrm{QO}_{2}$ in EMM 2 with elevated glucose. $\mathrm{O}$ $: \mathrm{QCO}_{2}$ in $\mathrm{EMM} 2.0: \mathrm{QCO}_{2}$ in EMM 2 with elevated glucose. B: protein, pg per cell. C: $\Delta$ : cells per $\mathrm{ml}$ culture, $\nabla:$ protein, $\mu \mathrm{g}$ per $\mathrm{ml}$ culture. D: respiratory quotient (RQ). $\mathrm{O}$ : in EMM 2, $\bullet$ : in EMM 2 with elevated glucose. 
K. Hamburger \& B. Kramhøft: Gaseous exchanges in Schizosaccharomyces

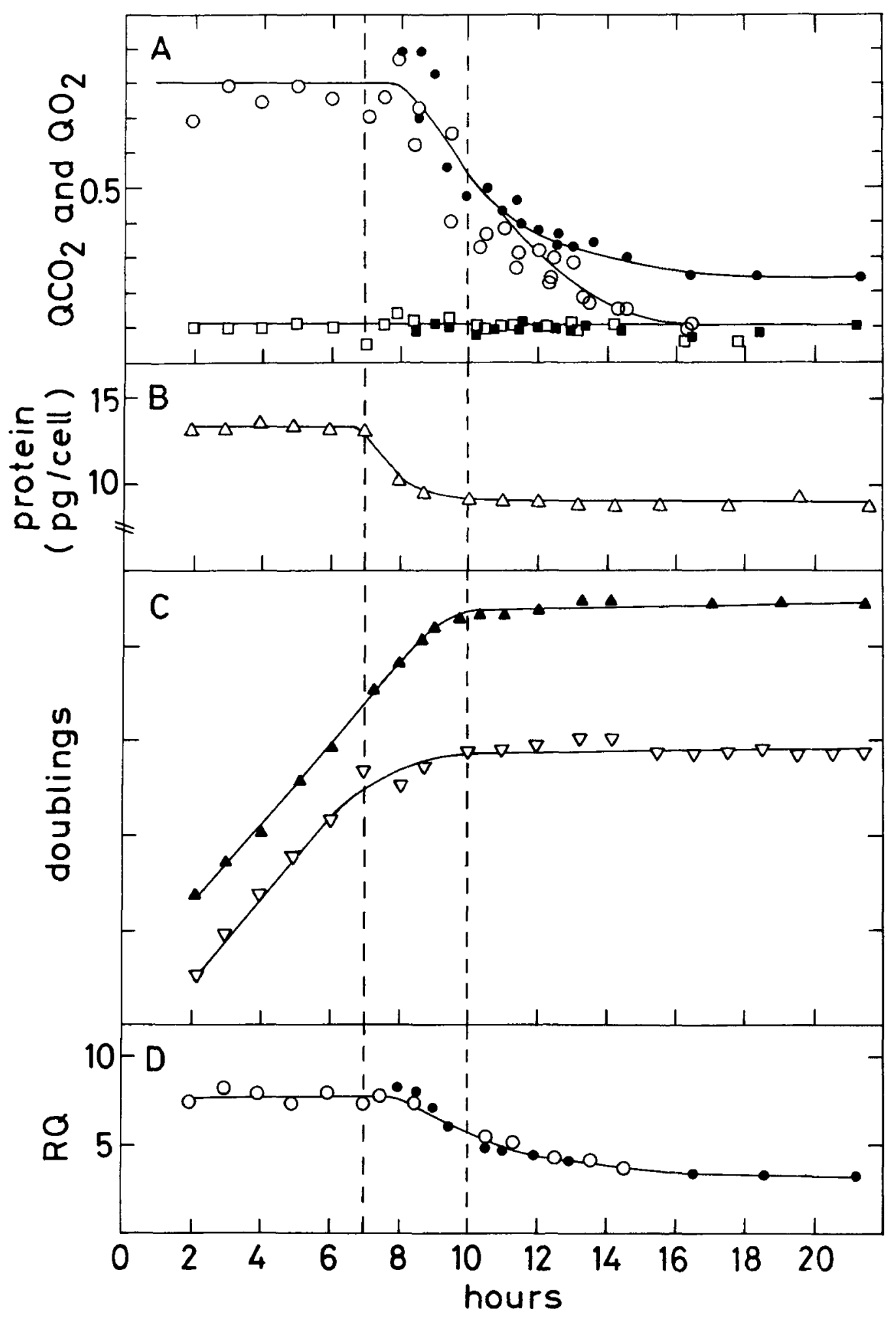




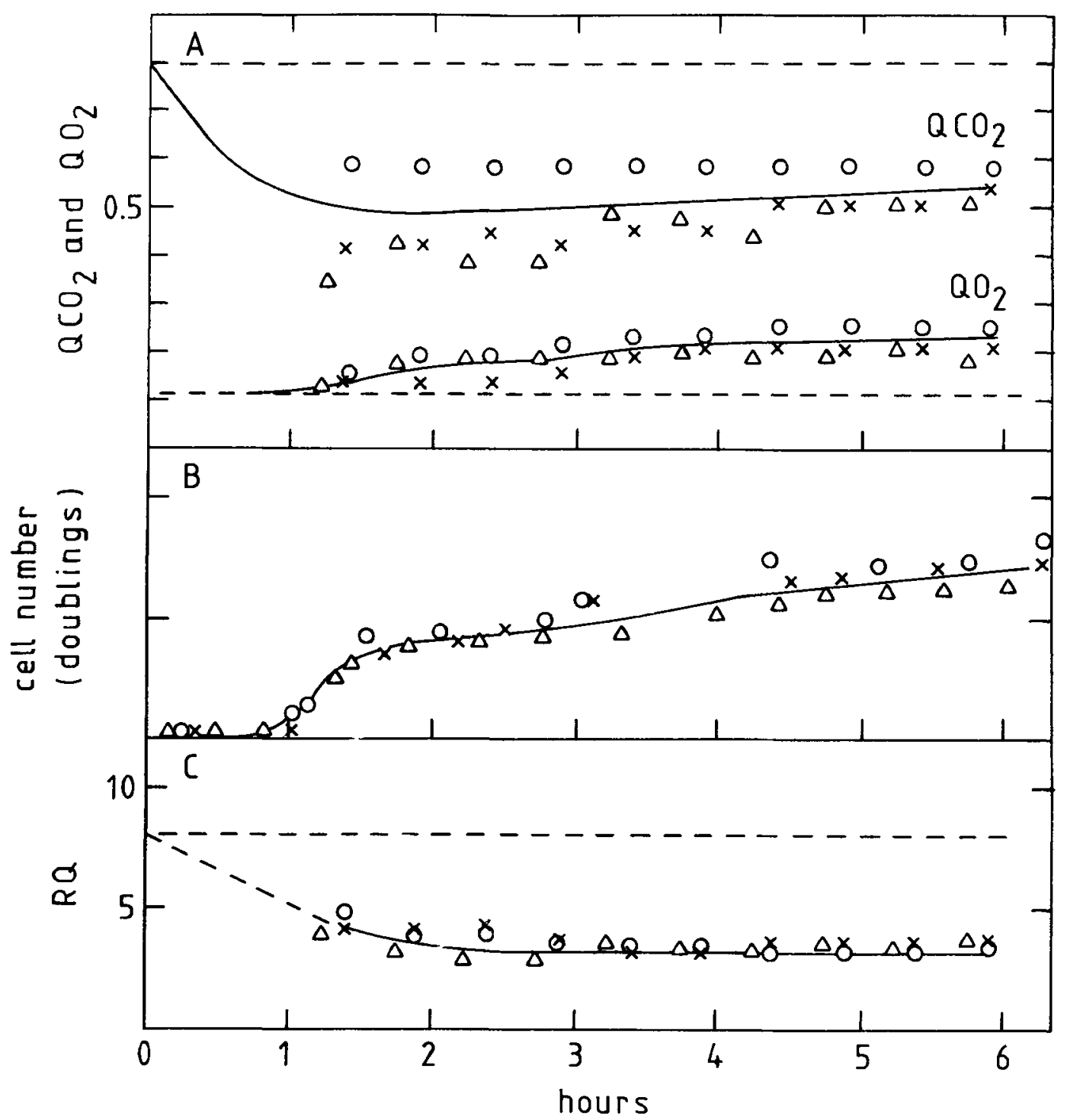

Figure 2. Gaseous exchanges and cell division of Schizosaccharomyces pombe in nitrogen free media.

A: oxygen uptake and $\mathrm{CO}_{2}$ production. B: cell number per $\mathrm{ml}$. C: respiratory quotient (RQ). The broken lines indicate control levels. $(x) \mathrm{KCl}$-medium, $(\Delta)$ choline chloride-medium, $(O)$ sorbitol-medium.

1. However, as indicated in the following the rate of fermentation is not determined by the medium glucose concentration per se. If the medium glucose concentration is increased to $5 \%$, the fermentation (Figure 1A, closed circles) decreases at the same rate during the transition phase as in the low glucose medium, in this case reaching a constant level, $\mathrm{QCO}_{2}=0.26$, in the late stationary phase, between 16 and 21 hours. The oxygen consumption (Figure 1A, closed squares) is unchanged. As a result of the changes in $\mathrm{QCO}, \mathrm{RQ}$
(Figure 1D, closed circles) decreases from 8 in exponentially multiplying cultures to 6 at the end of the transition phase, eventually reaching a constant level of 3.5 in late stationary phase.

\subsection{Nitrogen depletion}

Cessation of growth (protein synthesis) may be achieved by substitution of the $\mathrm{NH}_{4} \mathrm{Cl}$ component of EMM 2 with for example $\mathrm{KCl}$, choline chloride or sorbitol. After transfer of exponentially growing cells to such a nitrogen free medi- 
um, the respiration rate about doubles, while the fermentation decreases by about $30-40 \%$. Figure 2 shows the variation with time in gas exchanges (A), cell number per $\mathrm{ml}(\mathrm{B})$ and in $\mathrm{RQ}$ (C) after transfer of cells to nitrogen free conditions. As shown (B), cell multiplication continues for some time. Net protein synthesis is, however, immediately arrested and protein content per $\mathrm{ml}$ culture stays constant throughout the experimental period (not shown). The result is the formation of extremely small cells.

$\mathrm{QO}_{2}$ gradually increases from 0.11 (control value in EMM 2) to about 0.2 after 4 hours in the nitrogen free medium. $\mathrm{QCO}_{2}$ on the other hand, decreases during the first hour from 0.8 (control value in EMM 2) to about 0.5 and remains then constant throughout the experimental period. As a consequence of these changes, the $R Q$ decreases from 8 to 3.6 during the first hour and is constant thereafter. After 24 hours in nitrogen free medium RQ is unchanged 3.6 (not shown). Almost identical results (Figure 2) are obtained whether the $\mathrm{NH}_{4} \mathrm{Cl}$ of EMM 2 is substituted with equiosmolar amounts of sorbitol (circles), choline chloride (triangles) or $\mathrm{KCl}$ (crosses). Thus an activation of respiration occurs after transfer of Schizosaccharomyces to nitrogen free conditions whereas fermentation is about $\mathbf{5 0 \%}$ suppressed.

The respiratory activity of nitrogen depleted cells was compared to that of fully aerobic cells. In Schizosaccharomyces a fully aerobic metabolism with $R Q=1$ is induced after replacement of medium glucose with glycerol (4). In this case we observed that $\mathrm{QO}_{2}$ is 0.30 during exponential growth and 0.27 in stationary phase cells. Consequently, the $\mathrm{QO}_{2}$ of nitrogen depleted cells increases to near the same level as that characteristic of fully aerobic cells.

\section{DISCUSSION}

In the presence of abundant glucose the fermentation rate of Schizosaccharomyces is high during the exponential growth phase, decreases during the transition phase and the early stationary phase, reaching a constant level in late stationary phase. Since the respiration rate remains constant throughout cultural growth the change in $R Q$ is solely due to changes in the fermentation rate. From these observations we conclude that during cultural growth the rate of fermentation, as distinct from respiration, is determined by the growth rate of the cells. Studies of this kind have not earlier been carried out with $S$. pombe. The results obtained by HesLot et al. (4) are not comparable to the present results because in their work, respiration and fermentation were measured after transfer of log-phase cells or stationary phase cells to a succinate- $\mathrm{NaOH}$ buffer (pH 4.2) with 5\% glucose; hence the metabolic rate was measured under nitrogen starvation conditions. The relatively low $R Q$ values found by HesLot et al. (3.8 in cells in exponential growth and 1.6 in stationary phase cells) may thus be explained as a result of the nitrogen starvation conditions. With respect to Saccharomyces cerevisiae grown in continuous cultures under conditions of glucose limitation, $v$. Meyenburg (10) argued that the growth rate and not the extracellular glucose concentration limits the fermentation rate: with decreasing growth rate, $\mathrm{QO}_{2}$ increases and $\mathrm{QCO}_{2}$ decreases with the result that the metabolism gradually changes towards a more aerobic mode. Thus, the mechanisms underlying the regulation of the metabolism may well be of similar nature in Schizosaccharomyces and Saccharomyces.

In $\mathrm{S}$. pombe the oxygen consumption is constant throughout cultural growth. Thus, a possible derepression of respiratory enzyme synthesis could not be demonstrated. However, direct measurements of the amount of several mitochondrial respiratory enzymes have revealed the existence of an activation of enzyme synthesis in $S$. pombe during the growth cycle. This was demonstrated by POOLE and LLOYD who showed a specific increase in for example cytochrome oxidase and succinic dehydrogenase simultaneous with cessation of cell multiplication and the transition of the population into stationary phase (12).

The present work suggests that activation of respiration is induced by nitrogen deprivation. The rate of respiration is increased about 2 fold and almost to the level characteristic of fully aerobic cells. $\mathrm{QCO}_{2}$, on the other hand, decreased under these conditions. The fact that identical results are obtained whether $\mathrm{NH}_{4} \mathrm{Cl}$ is substituted with $\mathrm{KCl}$, choline chloride or sorbitol strongly suggests that the increased $\mathrm{QO}_{2}$ is a con- 
sequence of nitrogen deprivation rather than of the change in ionic composition of the medium. These observations differ somewhat from results with Saccharomyces, where LAGUNAS reported a decrease in the rate of fermentation and no increase in respiration as a consequence of nitrogen deprivation (7).

The question is whether the increased oxygen uptake in nitrogen starved cells is mediated via the cytochrome chain or via an alternative oxidase system. Respiratory activity mediated via alternative oxidase systems has been described in plant tissue, many microorganisms including yeasts (references in 1) and is induced in Schizosaccharomyces under anaerobiosis (4). In contrast to normal respiration these enzyme systems are not sensitive to Antimycin A or $\mathrm{KCN}$. When nitrogen deprived cultures of Schizosaccharomyces were treated with $0.05 \mu \mathrm{g}$ per $\mathrm{ml}$ of Antimycin $\mathrm{A}$, the $\mathrm{O}_{2}$ uptake was reduced to the same level as that of Antimycin treated control cells grown in EMM 2 with either glucose or glycerol as carbon source (unpublished). Consequently, we conclude that the increased respiration observed in nitrogen depleted cells is mediated via the cytochrome chain, and that nitrogen deprivation results in induction of synthesis as well as activity of respiratory enzymes.

Cessation of growth in S. pombe, whether induced by nitrogen starvation or stationary phase conditions, results in a decrease of the $R Q$ to the same level $(R Q=3.5)$ although the rate of respiration and fermentation is about twice as high in nitrogen starved cells as in stationary phase cells. However, if the oxygen consumption is calculated on a per cell basis, it appears to be the same in the two types of cells as demonstrated in Table II. These values were calculated from meausured values of cell number, protein per $\mathrm{ml}$ and $\mathrm{QO}_{2}$. In all cases, the respiratory activity was about $1 \times$ $10^{-6} \mu \mathrm{l} \cdot \mathrm{cell}^{-1} \cdot \mathrm{h}^{-1}$. This observation suggests that the rapid cell multiplication following removal of the nitrogen source is accompanied specifically by synthesis of respiratory enzymes or alternatively, the synthesis of mitochondrial material, at the expense of other cellular proteins.

\section{ACKNOWLEDGEMENTS}

The authors wish to thank Helga Sørensen for valuable technical assistance.

\section{REFERENCES}

1. Ainsworth, P.J., A.J.S. Ball \& E. Reno TUSTANOFF: Cyanide-resistent respiration in yeast. Arch. Biochem. Biophys. 202, 172-186 (1980)

2. De Deken, R.H.: The Crabtree effect and its relation to the petite mutation. J. Gen. Microbiol. 44, 157-165 (1966)

3. Hamburger, K., B. Kramhøft, S.B. NisSen \& E. ZEUTHEN: Linear increase in glycolytic activity through the cell cycle of Schizosaccharomyces pombe $972 \mathrm{~h}^{-}$. J. Cell Sci. 24, 69-79 (1977)

4. Heslot, H., A. Goffeau \& C. Louis: Respiratory metabolism of a "petite negative" yeast Schizosaccharomyces pombe $972 \mathrm{~h}^{-1}$. J. Bacteriol. 104, 473-481 (1970)

5. Kramhoft, B., S.B. Nissen \& E. Zeuthen: The cell cycle in heat- and selection-synchronized Scizosaccharomyces pombe. Carlsberg Res. Commun. 41, 15-25 (1976)

6. KRAmhøft, B. \& E. ZeUthen: Synchronization of cell division in the fission yeast Schizosaccharomyces pombe using heat shocks. Compt. Rend. Trav. Lab. Carlsberg 38, 351-368 (1971)

Table 11.

The respiratory activity of non-growing Schizosaccharomyces pombe.

\begin{tabular}{llcc}
\hline & $\mathrm{QO}_{2}$ & pg prot. cell ${ }^{-1}$ & $\mu 0_{2} \cdot$ cell $^{-1} \cdot \mathrm{h}^{-1}$ \\
\hline Stationary phase, 5\% glucose & 0.11 & 9 & $0.99 \times 10^{-6}$ \\
Nitrogen depleted, $\mathrm{KCl}$ & 0.20 & 4.7 & $0.94 \times 10^{-6}$ \\
Nitrogen depleted, choline Cl & 0.20 & 4.7 & $0.94 \times 10^{-6}$ \\
Nitrogen depleted, sorbitol & 0.25 & 3.6 & $0.91 \times 10^{-6}$ \\
\hline
\end{tabular}

All values were measured 6 hours after transfer to nitrogen-free medium. 
7. LaGunas, R.: Energetic irrelevance of aerobiosis for $S$. cerevisiae growing on sugars. Mol. Cell. Biochem. 27, 139-146 (1979)

8. Lehninger, A.L.: Biochemistry. Worth Publishers, New York (1975)

9. Lowry, O.H., N.J. Rosebrough, A.L. Farr \& R.J. RaNDalL: Protein measurement with the folin phenol reagent. J. Biol. Chem. 193, 265$271(1951)$

0. Meyenburg, K. v.: Katabolit-Repression und der Sprossungszyklus von Saccharomyces cerevisiae. Thesis, University of Zurich (1969)
11. Mitchison, J.M.: Physiological and cytological methods for Schizosaccharomyces pombe. In: Methods in Cell Physiology IV (D.M. Prescott ed.) Academic Press, pp. 131-165 (1970)

12. Poole, R.K. \& D. LLOYD: Oscillations of enzyme activities during the cell-cycle of a glucose-repressed fission-yeast Schizosaccharomyces pombe $972 \mathrm{~h}^{-}$. Biochem. J. 136, 195207 (1973)

13. UMBreit, W.W., R.H. BuRris \& J.F. StAuFFER: Manometric and Biochemical Techniques. Burgess (1972) 